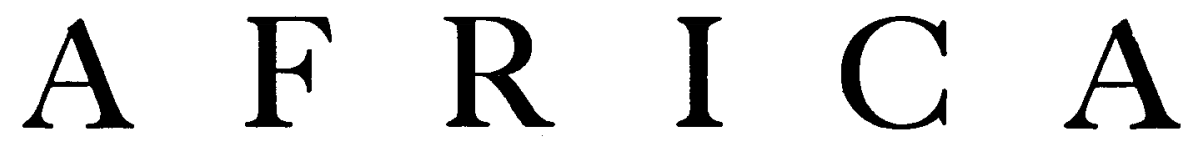

JOURNAL OF THE INTERNATIONAL INSTITUTE OF AFRICAN LANGUAGES AND C ULTURES

\title{
TO THE MEMBERS OF THE INSTITUTE
}

THE reappearance of Africa in something approaching its original form, will 1 indicate to our members that the Institute is gradually resuming its normal functions. At the same time, the general interest in African problems, as shown by the inquiries received here, and the evident need for a general clearing house of information on African questions, have made it necessary to consider a further enlargement of the Institute's scope and interest. This will involve the expansion and reorganization of the London office, and as soon as this has been effected one of our fitst duties will be to revise and bring up to date the list of our members, inviting all those who wish to continue their membership to renew their subscriptions. In the meantime, we wish to express our gratitude and appreciation to those of our members who have continued to support the Institute by paying their subscriptions during these last four years when we were forced to reduce our activities to a minimum.

This number of Africa is devoted to a discussion of various aspects of indigenous arts and industries, their development in modern industrial and economic conditions, and some of the problems likely to arise in the course of such development. The future well-being of African peoples largely depends on the successful solution of these problems. It is therefore of great importance that they should be carefully considered from all points of view by both Africans and Europeans. We hope that the articles by Mr. Stopford, Mr. Murray and Mrs. Cahan will stimulate thought and discussion on these matters.

Mr. Meyerowitz, in the course of the address which is reported in this number, pointed out how much those who are engaged in studying these problems in Africa could learn from the experience of people who are in touch with similar or related developments elsewhere. For this reason we have included notes and articles about the development of native arts and industries in Russia, Poland, China, India, Palestine, and the United States of America. Mr. Antoni Plutynski has given a description of the revival of the ancient Polish craft of weaving and its effects both on the life of village communities and on the taste of the more sophisticated urban populations. Mr. Phillips of the Tass Agency has contributed an account of the development of rural crafts in some of the Mongolian communities in the U.S.S.R., and the growth of the co-operative movement in this connexion. We have been

'Africa', the Journal of the International Institute of African Languages and Cultures, is published by the Institute, but except where otherwise stated the writers of the articles are alone responsible for the opinions expressed.

During the war the Journal will only be available to members of the Institute. 
able to include in Notes and News information about the work of the Chinese Industrial Co-operatives, about Indian crafts in the United States, and about peasant industries in Palestine. We hope to publish in a later number further reports from Palestine and Turkey.

We shall be glad to receive comments and short articles on this subject from any of our readers who have first-hand knowledge of such experiments or activities undertaken in Africa or elsewhere, and to give further information in reply to questions.

Just as we were going to press, the article by Professor Monod which appears in this number arrived from Dakar. It gives us great pleasure to be in touch again with Afrique Occidentale Française. Members will be interested to see what M. Monod says about the French attitude to indigenous crafts on the Ivory Coast. The attempt being made to prevent their degenerating to the level of commercial production for the tourist market is very relevant to the main subject of this number of Africa.

Members will be interested to hear that Dr. Ida Ward, head of the African Department at the School of Oriental and African Studies in London, and Chairman of our Interim Committee, intends shortly to leave for the Gold Coast, where she has been asked to do some important linguistic research for the Education Department. Another member of the Interim Committee, Dr. Margaret Read of the Colonial Department, Institute of Education, has been appointed a member of Mr. Walter Elliot's commission on higher education in Africa.

Dr. and Mrs. J. D. Krige's book, The Realm of a Rain Queen, the publication of which was announced in our last issue, has had an extremely good reception by the public and the first edition has already been sold out. A review of this book, which unfortunately did not reach us in time for inclusion in this number, will appear in the January number of Africa.

In the person of the Rev. William Paton, D.D., who died on August 2 Ist at the age of only 57, the Institute and many of its members have lost a good friend. He was appointed Secretary of the International Missionary Council in 1927, and since 1938, when Dr. Oldham retired, he carried on alone the work of the British section. He was greatly interested in African Missions, especially in Portuguese and Belgian territories.

We also deeply regret the death, on 22 July, of Professor R. F. A. Hoernlé, of Witwaterstand University, Johannesburg, who was for many years in close touch with this Institute and a contributor to Africa. He was esteemed as a distinguished scholar and philosopher both in this country and the United States, while his work as President of the South African Institute of Race Relations, and, during the war, as chief organizer of the South African Army Education scheme, earned him the respect and admiration of all friends of Africa.

HANNS VISCHER

Secretary-General and Acting Administrative Director. 